Woman in Russian Society

2020. No. 4. P. 126-136

DOI: $10.21064 /$ WinRS.2020.4.10
Женщина в российском обществе

2020. № 4. C. 126-136

ББК 63.3(2)6-284.3

DOI: $10.21064 /$ WinRS.2020.4.10

\title{
MUSLIM WOMEN UNDER SOVIET RULE IN CENTRAL ASIA (TURKISTAN): SOVIET GENDER PRACTICE
}

\author{
Y. Omarbayev ${ }^{\mathrm{a}}$, T. Khazretali ${ }^{\mathrm{b}}$, \\ E. Zulpikharova ${ }^{\mathrm{b}}$, Zh. Kumganbayev $^{\mathrm{c}}$ \\ a Institute "Public consent" under the President of Republic of Kazakhstan, \\ Nur-Sultan, Republic of Kazakhstan, omarbayev1987@gmail.com \\ ${ }^{\mathrm{b}}$ Khoja Akhmet Yassawi International Kazakh-Turkish University, \\ Turkistan, Republic of Kazakhstan \\ ${ }^{c}$ Al-Farabi Kazakh National University, \\ Almaty, Republic of Kazakhstan
}

After the October revolution of 1917, the lifestyle of Muslim women in Central Asia changed dramatically. This was due to the gender policy of the Bolsheviks. This study analyzes the Soviet Central Asia from a historical perspective to understand the impact of the Soviet regime on Muslim women's lifestyles. It specifically focuses on the underlying reasons of laws and policies put into effect by the Soviet officials in the name of emancipating Muslim women in Central Asia. The main argument of the study is that even though the Soviet officials had a genuine intention for the emancipation of Central Asian women from the patriarchal structure both in the public and private spheres of life, the policies and their implementations were shaped in accordance with the basic motive of the regime to survive. In the first years of the Soviet regime, mostly ideological intentions shaped the women's emancipation project.

Key words: Central Asia, Muslim women, Soviet Union, women's emancipation, Soviet gender policies, Muslim tradition, marriage.

(C) Omarbayev Y., Khazretali T., Zulpikharova E., Kumganbayev Zh., 2020 


\title{
МУСУ ЯЬМАНСКИЕ ЖЕНЩИНЫ ПРИ СОВЕТСКОЙ ВЛАСТИ В ЦЕНТРАЯЬНОЙ АЗИИ (ТУРКЕСТАН): СОВЕТСКАЯ ГЕНДЕРНАЯ ПРАКТИКА
}

\author{
Ы. Омарбаев", Т. Хазретали", \\ Э. Зулпьхарова ${ }^{\mathrm{b}}$ Ж. Кумганбаев \\ a Республиканское государственное учреждение "Қоғамдық келісім" \\ при Президенте Республики Казахстан, \\ г. Нур-Султан, Казахстан, omarbayev1987@gmail.com \\ ${ }^{\mathrm{b}}$ Международный казахско-турецкий университет им. Ходжи Ахмеда Ясави, \\ г. Туркестан, Казахстан \\ ${ }^{\mathrm{c}}$ Казахский национальный университет им. аль-Фараби, \\ г. Алматы, Казахстан
}

После Октябрьской революции 1917 г. положение мусульманских женщин в Средней Азии резко изменилось. Это было связано с гендерной политикой большевиков. В статье с исторической точки зрения анализируется влияние советского режима на трансформацию образа жизни мусульманских женщин Центральной Азии. Особое внимание уделяется основным причинам введения советскими официальными органами новых законов и осуществления политики эмансипации женщин. Главный вывод исследования состоит в том, что важнейшим мотивом реализации данной политики являлась борьба за выживание режима, хотя советские чиновники действительно стремились к освобождению среднеазиатских женщин как в общественной, так и в частной сфере жизни. В первые годы советской власти проект эмансипации женщин формировался главным образом на основе идеологии правящей партии.

Ключевые слова: Центральная Азия, мусульманские женщины, Советский Союз, эмансипация женщин, советская гендерная политика, мусульманская традиция, брак.

\section{Introduction}

After the Bolshevik Revolution of 1917, USSR (Union of Soviet Socialist Republics) was founded claiming to establish the first Communist regime in the world. The new Union tried to solve the economic, political and social problems to establish strong and indestructible socialist regime in the long run. Many legal regulations and propaganda tools were used for this purpose. In Central Asia, as elsewhere in the Union, Soviet regime tried to achieve a union economy, establish a state, which is atheist, egalitarian and secular, and to create a Soviet people sharing the same values regardless of their linguistic, cultural and traditional differences. In addition to these, the Soviet Union tried to change, destroy, or solve the issues related to the traditional life style of Central Asian people.

"Women's emancipation" was one of the items on the Soviet agenda. Emancipation, throughout this article, refers the liberation of women from enslavement to men and from traditional boundaries and stereotypes with the help of entering 
into the workforce and elimination of religious customs with reference to Soviet definition. It seems that the Bolsheviks approach to "women's emancipation" focused on the economic and political spheres. They strongly believed that they needed women to create a Communist society and to make it last. Women were assumed to be the mothers of future Communist generations, and the Soviet Union encouraged political and economic participation of women all over the Union regardless of different characteristics of different regions. Both within the family and in social, economic and political life, women were supported to become a modern Soviet woman fulfilling their responsibilities and expected to make decisions based on her own free will. However, under the Soviet regime, what a woman should or should not do were defined within strict boundaries, according to the needs of time/ the regime. Therefore, while Soviet Union tried to improve situation of women in the society, the regime also put them under heavy responsibilities and roles that women could not manage all the time. It seems to be there is a contradiction here in the Soviet vision, between seeing them as mothers (of the Soviet generation), fulfilling their responsibilities and free will. Maybe Soviet regime just wanted to switch women's loyalty and subservience from the family etc. to the new state, but not liberate them.

The literature on Soviet policies regarding women often revolve around the question of whether "women's emancipation" was achieved or not. More specifically, the motivations behind this Soviet project are analyzed. Was it ideologically or pragmatically driven? How vital woman emancipation was women's emancipation for the survival of the Soviet regime? How was it used to justify the Soviet policies? These are among the main questions discussed in the literature. Within this broad topic, the position of Muslim women of Central Asia make-up an interesting case. This paper will specifically focus on Soviet policies regarding women in Central Asian Republics for a few reasons. The paper consists of three parts. In the first part, we discuss the importance of this study, and the questions in mind regarding the subject. In the second part, after briefly discussing the pre-Soviet era, we focus on the position of Muslim women in Central Asia under Soviet regime in terms of legal, socio-cultural, economic and political spheres. And, in the last part, we evaluate the Soviet era policies regarding Muslim women.

In this paper, how being a Muslim and having strong cultural traditions affected the woman issue in Central Asia will be examined. The research question in mind is that; was gender equality achieved under Soviet Union in Central Asia? Answering the questions of was the equality before law enough to create gender equality in the society? and did participation of work result in emancipation of women? To answer these research questions, Muslim women under Soviet regime are analyzed. Legal, political, economic, and social regulations put into effect by Soviet Union are examined.

The reason making Central Asian region important to study, and not any other Muslim country, is that people in this region experienced foreign domination in their lands and were forced to accept certain gender-based policies put into effect by foreign policy makers. These policies were from the above, and sometimes ignored the necessities and values of the people living in that region. Moreover, the atheist ideology of the Soviet regime saw religion (Islam) as a major threat. This is yet another reason that makes Central Asia unique in terms of the gender issue. 
In the literature, on the one side, there are studies related to Soviet women and focusing on the ideological motivations of Soviet authorities on gender issue [Abashin, 2015: 94]. On the other side, there are studies on Central Asian women. These studies mainly focus on the pre-Soviet period Central Asian women who were characterized with bride price, child marriage, and isolation from the outside world via veil, polygamy, violence and male domination. After the arrival of Soviets to the region, feudal culture of the region was confronted with the Soviet ideology. Emancipation of women was the vital part of Soviet policies, because religious customs and traditions caused Central Asian women to be perceived as slaves by the new regime.

Although there are many studies focusing on the Central Asian history and the transition period of these countries analyzing social, economic and cultural policies, very few scholars in Russia, Kazakhstan and Uzbekistan have studied the subject of women in Central Asia; and these works mainly focused on the gender issue within a comparative perspective [Sydykova, 2014; Abashin, 2015].

Therefore, this study aims at contributing to this literature by focusing on the life of women in the region, and how and why this changed or was changed during the Soviet era in a historical perspective.

\section{Gender policy of the Bolsheviks in Central Asia}

The situation of Muslim women changed in the Soviet era because women were the visible side of the Communist revolution. Leaders of Communist Party believed that emancipation of women was the first step for the emancipation of all.

Many scholars suggest that gender policies were not all about achieving gender equality, but about solving the current demographic, economic and ideological problems that the Soviet Union faced [Lubin, 1981: 186].

From the beginning of their rule, we believe that Soviet leaders tried hard to liberate women in all the regions of the country. The ideal was to equalize woman with man in the economic, social and political spheres. To do so, Soviet leaders provided moral and material support for helping women in their role as mothers and wives. However, the aims of Soviet Union are regarding women's emancipation different conditions and different ways in different regions of the Union. Lubin indicates that while Soviet policies regarding the female emancipation was a legal matter, in Central Asia, it was not about the social and economic norms, but a matter of religious and traditional society [ibid.: 182].

Especially in the rural areas of Soviet Union, women had no public role and enjoyed only a few rights. They had no right to divorce, for example. Under Islamic law, they had formal rights in theory, but in practice, it was difficult to enjoy these rights, if not impossible. The very first duty of the woman was childbearing, i. e. having a large number of sons for the well-being of the family. Health care provided to women was primitive. It was expected of women to work and give birth at the same time. These circumstances led to infant mortality rate being rather high in Central Asia. In addition, physical punishment to women was common. It was claimed by Massell that, "a husband catching a runaway wife might bite off her nose, and the branding of genitals in cases of female infidelity was also discovered" [KennedyPipe, 2004: 94]. 
Massell points out that Central Asian women were perceived by society, and by themselves as "the lowest of the low", "the most oppressed of the oppressed", "the most enslaved of the enslaved" [Massell, 2010: 93]. Therefore, he made five assumptions regarding Central Asia and Central Asian women. Firstly, every society has antagonisms that would be put an end to by communism. Secondly, in Central Asia, two main reasons stood out for the lack of social struggle; the process of struggle could be masked by the notion of solidarity, and if the parties failed to behave in an expected manner, the problem could be solved by the strong kinship relations before it caused fragmentation. Therefore, there was a need for a different approach towards Central Asia. Thirdly, Muslim traditions were a unique target for revolutionary purposes, and women could be the main respondents of these purposes. Fourthly, women needed to be free from the chains of tradition, so that they could actively take part in the revolution. Lastly, female resentment and discontent would make women the revolutionary force in Central Asia.

Soviet Union had to eliminate all above-mentioned mentality of women's subordination to achieve its purposes. For Soviet leaders, it was not possible to build a Socialist state without liberating women. So, they tried to change the subordinate status of women by recruiting them into Soviet collective farms, factories and schools. It was their way to fight against the backwardness of Muslim women in Central Asia. Soviet authorities believed that, by eradicating the customs and traditions, they could finally transform the Central Asian women. The final goal was to make Central Asian women active Soviet citizens. To achieve this end, negative elements in women's life in Central Asia were overemphasized. That intention of freeing women from all peculiarities they were born with does not necessarily guarantee desired results. As Keller claims, the Soviet policies for the emancipation of women in Uzbekistan had two components: freeing women from Muslim social and religious structures and placing them into the workforce. However, these emancipation attempts resulted in undesired outcomes when women were faced with the problem of creating balance between obeying the rules of the government, remaining royal to their families, communities, customs and, embracing their own opportunities to fulfill their desires. Therefore, women became the victims of the policies that were supposed to help improve their status in society [Keller, 1998: 20].

Soviet officials saw the Islam as the main cause of women's backwardness in Central Asia because they had to find such a component in the society to justify their policies as an atheist and Communist state. By this way, they have the chance to present themselves as the "saviors". So, they did not take what was written in the Koran or Sunna as a guide, their primary goal was to recruit women as the defenders of the new regime. There is quite a literature on whether Islam provided women more opportunities and enhance the position of women in the society, or it eradicated the women's status. However, this study does not focus on that issue; rather it underlines the latter view as the point of view of the Soviet Union .

Legal framework. In order to change the traditional way of life in Central Asia, the Soviet regime, made changes in the legal codes. Initial steps toward female emancipation were rather promising. In 1918, the first Family Code made women equal to men under the law. The code allowed women to choose their surname when they got married; gave illegitimate children the same legal rights as legitimate ones and eased 
the divorce process. Polygamy (polygyny), child marriage and bride wealth (kalym) were banned. This Code tried to achieve equality between husbands and wives, and to secularize marriage [Sydykova, 2014: 76].

In 1919, a Registry of Births, Marriage and Death was established in Turkistan [Omarbayev, 2017: 6]. In 1920, Islamic law (sharia law), and Islamic court system were replaced with secular law and courts. The regime set an age limit of 18 for males, and 16 for girls to get married. The Code of 1920 put an end to the religious sanction of marriage. The equality between man and woman was guaranteed. Equal pay for equal work was legalized [Edgar, 2003: 138].

New laws, also, concerned with the personal safety of women. Mistreatment and insulting of women were banned and forcing women to wear a veil became illegal [Turaeva, 2017: 61]. In 1920, abortion was legalized. Women's Bureau of Communist Party (Zhenotdel) was established in 1919 [CSA RU, fond R-27, opis' 1, delo 6, 28]. A circular was issued in 1926 to enhance female access to divorce via secular courts and it forbade the religious courts to hear divorce cases. In 1927, the commissariat issued a general call to form a "united front in the offensive against survivals of the old way of life for the liberation of women" no doubt in connection with the launching of the unveiling campaigns" [ibid., fond R-18, opis' 1, delo 19, 55].

"The Decree in Defense of Mother and Child" in 1936 was a historical turning point. Family as the foundation of society was emphasized. Under this decree, abortion was illegalized, homosexuality was declared as a crime, divorce became difficult to obtain and rights of illegitimate children were revised [Tatybekova, 1975: 13].

Protective labor legislation indicated that women should not work if it prevented their role as child bearers, and gave some special rights to pregnant women in the 1920s [Liubimova, 1925: 41]. It was assumed that financial support was needed for women to raise their children. This support was the key element of pronatalist (the belief that a woman's worth is tied to conceiving and bearing children, and motherhood is a primary social role of women) campaign for large families. In addition, visual material was used to emphasize the importance of motherhood and mothers.

Central Asian Republics passed laws identifying and outlawing "crimes of custom" (byt or bytovye prestupleniia meaning social, everyday life) in the 1920s [Vishnevski1̌, 1992: 85]. In the 1930s, the Communist Party declared that emancipation of women was achieved. However, in the post-war years, it was stated, "the postwar years saw a steady increase in the absolute number of abortions, an indication of the state's failure to reach women through pro-natalist and anti-abortion propaganda" [Ponomarev, 2010: 69]. In 1941, a decree on taxing bachelors, single and childless citizens of the USSR tried to encourage birth. After World War II, the Soviet Union put pro- natalist Family Law into effect. This law increased financial support for pregnant women, mothers with many children, single mothers, and preserved motherhood. Honorary title of Mother Heroine (awarded to those with ten children or more) was introduced. This law aimed to increase population. "Motherhood Medal", Khrushchev's proposal consisted of two documents; the informational note (spravka) "on measures for increasing the population of the USSR" and the draft ukaz "on measures to increase governmental support for women in childbirth and mothers 
with many children, and reinforcement of the protection of motherhood and childhood" [CSA RK, fond 35, opis' 1, delo 46, 17, 18].

The emancipation of women was imposed from above by the Soviet government, for affecting revolutionary changes, while not being concerned about economic, social and demographic issues. After a certain time period, Soviet policy makers believed that women question in the Union was solved, and gender equality was achieved regardless of different starting points, nationalities and traditions of the various regions [Lubin, 1981: 182-183]. However, the major problem was the reluctance of local party officials to implement the laws they deemed to be against their way of life and religion [Tartakovskaia, 1997: 41]. So, regime's influence remained weak in Central Asia, and the new laws remained unenforced in the longrun.

Socio-cultural arena. In Central Asia, daughters were expected to protect family honor, have roles in the public domain, to be modest, and to obey their parents and husbands. Sons were perceived more valuable as they were productive laborers as well as the ones bringing wives and children into the family. They were expected to take care of their parents in their old age. However, daughters would leave their families once married [Ponomarev, 2010: 56]. Women were to raise a child as a source of status and respect. Muslim women were bound by the Sharia (law based on the holy book of Muslims, the Qur'an) which was perceived as the protector of women and guarantor of their moral and spiritual superiority as mothers, wives, and daughters. The nomadic and settled populations in the region had different interpretations of the law.

Women in nomadic areas enjoyed more autonomy both in public and private spheres, as compared to women in settled areas [Abashin, 2015: 229]. The division of labor and tasks that women were handling gave them more freedom in rural areas, as compared to urban areas. Especially in the urban areas of Central Asia, women were not allowed to walk in the streets without male escort, when they did, they were expected to keep silent and segregated. A Turkmen saying clearly shows this view: "The world is a man's house, while the house is a woman's world" [Turaeva, 2019: 65].

Soviet leaders attempted to eliminate these views, customs and practices that oppressed women. They believed that this was the very first step of establishing socialism. Policy makers initiated some reforms eradicating the Islamic marriage and family practices. Child marriage, bride wealth and polygamy were outlawed to free women from the bondage of oppressive customs and to make them visible in schools, collective farms and public organizations [Engel, 1992: 314]. The regime interpreted that women in Central Asia were bound up with traditions due to illiteracy, ignorance, and superstition in cultural roles [Massell, 2010: 157]. However, as Abazov points out, traditions in Central Asia were products of long-term experiences. For example, the extended family structure provided a social safety net. Therefore, arranged marriages helped the survival of social stability [Abazov, 2007: 216]. The Soviet regime and Central Asian people did not view the traditional way of life in Central Asia from the same perspective. This was natural, but those different views made it difficult for the Soviet leaders to find a middle way and set a ground for their reforms. The daily life practices and customs of Muslim populations of Central Asia were unacceptable for the Soviet Union, and the destructive reforms initiated by the regime created resentment among the locals. Therefore, it was difficult to eliminate 
all the customs that defines Central Asian people. It was even more difficult for them to see their customs ascrimes [ibid.: 217].

The murders and harassment women faced with proved the inadequacy of legal sanctions to protect women. In 1938-1939, bride wealth and underage marriages cases of byt murders, sexual crimes and beatings of women increased [Ponomarev, 2010: 58]. Local police officers and prosecutors were not willing to punish these crimes, and this created the violence without any punishment. Men arrested for insulting unveiled women were sometimes released in as little as two hours [Abashin, 2015: 234]. Moreover, child marriage was another problematic issue. Between the years 1925 - 1935, almost half of the social crimes were about child marriage. It can be argued that Soviet policy makers failed to abolish the traditional practices. Attendances of mosques increased, fasting for Ramadan remained as widespread practices, and unveiled women turned to veil once again. With the relaxation of anti-religious campaign in 1930s, women's duties as Muslim women were re-emphasized [Keller, 1998: 31].

Therefore, in Central Asia, the laws were not enough to guarantee women's emancipation. Men and women internalized the customs. It was difficult to cut the tie between women and customs. Therefore, Soviet policy makers attempted to cut this tie by fighting over the most visible characteristic of women in Central Asia, the veil.

Family. Women were treated as second-class members of the family in Central Asia. They were treated as the source of honor for the family. They had to be silent and obey the rules that their families and traditions had set for them. The relationship between a father and a daughter was limited. Mostly, the father decided the man whom his daughter married, as Turkmen saying indicates, "just as a cow does not choose the water she drinks so does a woman not choose her husband". In marriage, the woman was the object of the contract, not the subject [Massell, 2010: 121].

After the Bolshevik Revolution, complete transformation of societies was envisioned. Transforming family structure was the part of it. Breaking up old family structures and formation of new ones was the motto of Soviet policies especially in the first decade of regime [Aleksandrova, 1946: 76]. The Soviet Union, to achieve its end goal of transforming all society, tried to transform families in general, and mothers in particular. The distinct characteristics of the Soviet Union was the ideal of "the angel in the home", and encouragement of women to work [Kelly, 2003: 115]. Turkmen men perceived this law as an assault to Turkmen family [Edgar, 2003: 144].

There is no doubt that men from other parts of the Central Asia also interpreted this law as Turkmen men. Consequences for women who dared to initiate divorce were dire, ending mostly murder by their husbands or women would often commit suicide since they had nobody to take care of them following their divorce. As one can observe, the policies towards emancipation of women in the region did not always result in the desired outcomes. These outcomes became more and more unpredictable when the regime modified its policies over time. The family was used as a unit of analysis according to the needs of the time and the policies of the leaders. For example, in 1934 Stalin emphasized the family as the basic unit of socialist society when preservation of the family structures was needed for his economic policies. This declaration aimed at preserving families, decreasing divorces and abortions, and giving rise to the birthrate [Kennedy-Pipe, 2004: 97]. S. N. Abashin claims that motherhood was promoted as a social duty as an explicit policy of Soviet Union. 
Pronatalist and maternalist policies put some value to the large families, especially in rural Central Asia. Central Asian women were encouraged to give birth with the awards like Heroine Mother and Motherhood Glory (given to those with seven to nine children) [Abashin, 2015: 314].

The main failure of the Soviet Union regarding the family structure was that the regime ignored the customs and traditions that were the very basis of family formation in the region. Policies were shaped based on the ideology of the Soviet Union because at the end, the regime aimed at creating a society without any particularities like religion, tradition, and ethnicity. However, Central Asian people were not familiar with the regime and its ideals, so they should not have been expected to understand and internalize the reasons of reforms affecting family dynamics.

\section{Conclusion}

In the 1920s, the Soviet regime tried to be free women from the burdens of traditional way of life, and its symbolic expressions such as the veil. In the 1930s and 1940s, women were perceived as devoted workers on the way of creating socialism. Until the 1950s, there was not much discussion on the roles of the women. After the death of Stalin, the woman question returned to the public arena. In 1956, Khrushchev underlined the importance of women's active participation in politics. In the 1980s, especially in education, women's successes were impressive [Sydykova, 2014: 62].

Summarizing the results of the study, one can argue that gender equality under the law was established formally in Soviet Central Asia; however, its practice shows that gender equality needs much more effort than legislative actions. Although the Soviet regime tried to tackle the woman issue, the main problem for the achievement of desired results was the misguided communication between the Central Asian population and Soviet officials. Soviet leaders and officials presented the problems related to the woman question within their own ideological perspectives. In theory, what was assumed by the Soviet Union is understandable. While emphasizing the subordinate position of women, and the traditional and religious customs, the Soviet Union tried to use the resentments of women to turn them to independent individuals in all spheres of life. However, they failed to understand whether or not the problems they defined were the actual problems preventing women's status to be higher in the society.

One cannot claim that Soviet policies towards women were completely successful or not. What can be claimed is that the policies were pragmatic ones in accordance with the necessities of the time. From the Soviet Union point of view, creation of the defined Soviet person, regardless gender, was the real purpose. Therefore, rather than emphasizing differences, they tried to emphasize common things for all Soviet countries. What was missing in Central Asia was the total understanding of the regime. The people did not know about socialism, they did not know about the consequences of socialism, and the reason behind the reforms related to women. In addition, the regime did not know about Islam, the meaning of Islamic traditions, and it did not try to understand the basic meanings of these traditions for the people of Central Asia. 


\section{References}

Abashin, S. N. (2015) Sovetskaia derevnia mezhdu kolonializmom i modernizatsier [The Soviet village between colonialism and modernization], Moscow: Novoe literatyrnoe obozrenie.

Abazov, R. (2007) Culture and Customs of the Central Asian Republics, London: Greenwood Press. Aleksandrova, V. (1946) The Soviet family, Russian Review, vol. 5, no. 2, pp. 74-82.

CSA RK (Central State Archive of the Republic of Kazakhstan, Almaty).

CSA RU (Central State Archive of the Republic of Uzbekistan, Tashkent).

Edgar, A. L. (2003) Emancipation of the unveiled: Turkmen women under Soviet rule, 19241929, Russian Review, vol. 62, no. 1, pp. 132-149.

Engel, B. A. (1992) Engendering Russia's history: women in post-emancipation Russia and the Soviet Union, Slavic Review, vol. 51, iss. 2, pp. 309-321.

Keller, Sh. (1998) Trapped between state and society: women's liberation and Islam in Soviet Uzbekistan, 1926-1941, Journal of Women's History, no. 10, pp. $20-44$.

Kelly, K. (2003) Malen'kie grazhdane bol'shoî strany: internatsionalizm, deti i sovetskaia propaganda [Small citizens of a big country: internationalism, children and Soviet propaganda], Novoe literatyrnoe obozrenie, no. 3, pp. 114-128.

Kennedy-Pipe, C. (2004) Whose security?: state-building and the emancipation of women in Central Asia, International Relations, vol. 18, iss. 1, pp. 91-107.

Liubimova, S. (1925) Kak zhivut i rabotaiut zhenshchiny Tsentral'noù Azii [How Central Asian women live and work], Leningrad: Gosydarstvennoe izdatel'stvo.

Lubin, N. (1981) Women in Soviet Central Asia: progress and contradictions, Soviet Studies, vol. 33, iss. 2, pp. 182-203.

Massell, G. J. (2010) The Surrogate Proletariat: Moslem Women and Revolutionary Strategies in Soviet Central Asia, 1919-1929, Princeton: Princeton University Press.

Omarbayev, Y. K. (2017) Influence of passport documents on different spheres of activity life of Kazakhs pre Soviet period, Norwegian Journal of Development of the International Science, vol. 2, no. 4, pp. 67-72.

Ponomarev, E. G. (2010) Obrazovanie i vospitanie detě̃. Deti sovetskou strany, 1917-1941: (Antropologicheskii aspekt) [Education and upbringing of children. Children of the Soviet country, 1917-1941: (Anthropological aspect)], Stavropol: Izdatel'stvo Stavropol'skogo gosudarstvennogo pedagogicheskogo instituta.

Sydykova, A. A. (2014) Polozhenie sovetskikh zhenshchin v Kazakhstane [The situation of Soviet women in Kazakhstan], Almaty: Kazakhskiĩ natsional'nyi universitet.

Tartakovskaia, I. (1997) Sotsiologiia gendera $i$ sem 'i [Sociology of gender and family], Samara.

Tatybekova, J. S. (1975) Oktiabr' $i$ zhenshchiny Kyrgyzstana [October and women of Kyrgyzstan], Frunze: Kirgizstan.

Turaeva, R. (2019) Women as change agents: gender in Post-Soviet Central Asia, in: Najafizadeh, M., Lindsey, L. (eds), Women of Asia: Globalization, Development, and Gender Equity, New York: Routledge, pp. $424-437$.

Vishnevskiī, A. G. (1992) Evvoliutsiia sem'i $i$ semeinoĭ politiki SSSR [Evolution of the family and family policy of the USSR], Moscow: Nauka. 


\section{Информация об авторах / Information about the authors}

Omarbayev Yrysbek - $\mathrm{PhD}$, Chief Expert, Institute "Public consent" under the President of Republic of Kazakhstan, Nur-Sultan, Republic of Kazakhstan, omarbayev1987@gmail.com (PhD, главный эксперт, Республиканское государственное учреждение "Қоғамдық келісім" при Президенте Республики Казахстан, г. Нур-Султан, Казахстан).

Khazretali Tursun - Dr. Sc. (History), Professor, Khoja Akhmet Yassawi International Kazakh-Turkish University, Turkistan, Republic of Kazakhstan (доктор исторических наук, профессор, Международный казахско-турецкий университет им. Ходжи Ахмеда Ясави, г. Туркестан, Казахстан).

Zulpikharova Elmira - Cand. Sc. (History), Assistent Professor, Khoja Akhmet Yassawi International Kazakh-Turkish University, Turkistan, Republic of Kazakhstan (кандидат исторических наук, доцент, Международный казахско-турецкий университет им. Ходжи Ахмеда Ясави, г. Туркестан, Казахстан).

Kumganbayev Zhandos - PhD, Assistent Professor, Al-Farabi Kazakh National University, Almaty, Republic of Kazakhstan ( $\mathrm{PhD}$, доцент, Казахский национальный университет им. аль-Фараби, г. Алматы, Казахстан). 